\title{
С.В. ПОЛИВАНИЙ
}

Вінницький державний педагогічний університет імені М. Коцюбинського вул. Острозького, 32, Вінниця, 21100

e-mail: stepan.polivaniy@ukr.net

\section{ВПЛИВ РЕГУЛЯТОРІВ РОСТУ НА ОСОБЛИВОСТІ ПЕРЕРОЗПОДІЛУ ЕЛЕМЕНТІВ МІНЕРАЛЬНОГО ЖИВЛЕННЯ ТА ПРОДУКТИВНІСТЬ РОСЛИН МАКУ ОЛІЙНОГО}

В умовах польового досліду вивчали вплив хлормекватхлориду, трептолему та суміші трептолему і хлормекватхлориду на морфологічні особливості, накопичення та перерозподіл азоту, фосфору і калію рослинами маку олійного. Встановлено, що обробка рослин маку регуляторами росту інтенсифікувала галуження стебла, збільшувала кількість, площу та масу листків. Обробка трептолемом, хормекватхлоридом, сумішшю препаратів призводила до потовщення основної асиміляційної тканини листка хлоренхіми внаслідок розростання іiі клітин. У результаті цих змін фотосинтетичного апарату суттєво підвищувався донорний потенціал рослин маку олійного. Внаслідок посиленого галуження стебла за дії препаратів закладалася додаткова кількість нових атрагуючих центрів - коробочок. Це спричинило перерозподіл надлишку елементів мінерального живлення в бік формування плодів.

Ключові слова: мак олійний (Рараver somniferum L.), регулятори росту рослин, мезоструктура листків, морфогенез, елементи мінерального живлення, продуктивність

Вивчення закономірностей функціонування донорно-акцепторної системи рослин з метою розробки засобів перерозподілу потоків асимілятів до господарсько-важливих органів $\epsilon$ актуальним завданням сучасної фізіології рослин. Оскільки регулятори росту рослин суттєво впливають на морфогенез, з'являється можливість встановити, через які анатомо-морфологічні та фізіологічні зміни посилюється або послаблюється транспорт потоків асимілятів до різних органів і тканин рослини. Такий підхід дозволяє встановити не лише перерозподіл продуктів фотосинтезу між вегетативними та генеративними органами рослини, але й мінеральних елементів між ними при різній швидкості росту.

Разом з тим інформація щодо перерозподілу азотовмісних сполук між органами рослин у процесі вегетації за дії регуляторів росту досить суперечлива та розрізнена [11]. Зокрема, за дії хлормекватхлориду (ХМХ) підвищувався вміст білкового азоту в листках і стеблах соняшника [14]. Обробка рослин цукрового буряка різними концентраціями паклобутразолу також зумовлювала збільшення вмісту загального азоту в листках та зменшенні загальної кількість азоту в коренеплодах на кінець вегетації [17], а за обробки ріпаку препаратом встановлено, що в період цвітіння і росту стручків вміст білкового азоту в тканинах вегетативних органів зменшувався [13].

Препарати емістим С та агростимулін зумовлювали збільшення вмісту розчинних білків у листках і колосі пшениці [5]. Обробка емістимом С та агростимуліном також збільшує вміст азоту в рослин сої [18]. Разом з тим, емістим С не впливав або зменшував кількість білкового азоту у листках цукрового буряка [15], рослин люпину [10].

Таким чином, результати вивчення впливу різних типів регуляторів росту на вміст азоту у сільськогосподарських культур значною мірою суперечливі, а вплив регуляторів рослин на вміст азоту у рослин маку не вивчався зовсім.

Тому метою нашої роботи було з'ясувати вплив регуляторів росту на морфогенез рослин маку та накопичення і перерозподілу основних елементів мінерального живлення.

\section{Матеріал і методи досліджень}

Досліди проводили у 2012-2014 рр. в умовах Вінницької області на рослинах маку олійного сорту Беркут, рекомендованого для зон Лісостепу, Степу та Полісся України. Площа облікової 
ділянки - $10 \mathrm{~m}^{2}$, повторність дослідів п’ятикратна, ділянки розміщені рендомізовано. Рослини одноразово обробляли вранці у фенологічній стадії росту «бутонізація» водним розчином хлормекватхлориду $0,5 \%$-ної концентрації (за діючою речовиною), трептолему концентрацією 0,035 мл/л та сумішшю 0,5\%-го рочину хлоормекватхлориду та трептолему $(0,035$ мл/л) до повного змочування листків за допомогою ранцевого обприскувача ОП-2, контрольні рослини - водопровідною водою.

Морфометричні показники визначали кожні 10 днів, починаючи 3 дня обробки. Для біохімічного аналізу проби фіксували рідким азотом з наступним досушуванням у сушильній шафі при $85^{\circ} \mathrm{C}$. Площу листків визначали ваговим методом [4]. Мезоструктурну організацію листка дослідних рослин вивчали на фіксованому матеріалі. Для його консервації застосовували суміш рівних частин етилового спирту, гліцерину, води 3 додаванням $1 \%$-го формаліну. Визначення розмірів клітин i окремих тканин здійснювали за допомогою окулярного мікрометра МOB-1-15x. Для цього використовували часткову мацерацію тканин листка. Як мацеруючий агент було обрано $5 \%$-й розчин оцтової кислоти в 2 моль/л соляної кислоти [8]. Вміст фосфору визначали за утворенням фосфорно-молібденового комплексу, калію - полум'яно-фотометричним методом, загального азоту - методом Кельдаля [9]. Результати досліджень обробляли статистично за допомогою комп'ютерної програми «STATISTICA - 6». У таблицях і на рисунках подані середньоарифметичні значення та їх стандартні похибки [3].

\section{Результати досліджень та їх обговорення}

Застосування трептолему та суміші препаратів у стадії бутонізації призводило до посилення лінійного росту пагонів, а препарат хлормекватхлорид проявляв на рослинах маку олійного типову рістгальмуючу дію. При цьому відбувалося достовірне потовщення стебла в усіх варіантах досліду в порівнянні з контролем, що підвищувало стійкість рослин до полягання та створювало технологічні переваги при зборі урожаю (табл. 1).

Таблиия 1

Вплив регуляторів росту на морфометричні показники рослин маку олійного (стадія воскової стиглості)

\begin{tabular}{|c|c|c|c|c|}
\hline Показник & Контроль & $\begin{array}{c}\text { Суміш } \\
\text { препаратів }\end{array}$ & $\begin{array}{c}\text { Трептолем } \\
0,035 \text { мл/л }\end{array}$ & ХМХ 0,5\%-й \\
\hline Висота рослин, см & $104,45 \pm 1,77$ & $* 116,61 \pm 1,82$ & $* 112,59 \pm 1,65$ & $* 93,75 \pm 1,29$ \\
\hline Діаметр стебла, мм & $7,89 \pm 0,23$ & $* 9,26 \pm 0,27$ & $* 9,03 \pm 0,25$ & $* 9,24 \pm 0,31$ \\
\hline $\begin{array}{c}\text { Кількість пагонів другого } \\
\text { порядку, шт. }\end{array}$ & $2,49 \pm 0,09$ & $* 3,10 \pm 0,12$ & $* 2,97 \pm 0,12$ & $* 3,01 \pm 0,11$ \\
\hline Кількість листків, шт. & $19,18 \pm 0,49$ & $* 23,59 \pm 0,45$ & $* 22,76 \pm 0,47$ & $* 22,54 \pm 0,52$ \\
\hline Маса сухої речовини листків, г & $4,31 \pm 0,19$ & $* 5,16 \pm 0,17$ & $* 5,12 \pm 0,18$ & $* 5,09 \pm 0,20$ \\
\hline Площа листків, дм ${ }^{2}$ & $11,47 \pm 0,27$ & $* 14,12 \pm 0,35$ & $* 14,03 \pm 0,33$ & $* 13,98 \pm 0,32$ \\
\hline
\end{tabular}

Примітки: *-різниця достовірна при $\mathrm{P} \leq 0,05$; суміш препаратів - трептолем $(0,035$ мл/л) + ХMX 05\%-й

Формування донорного потенціалу рослини насамперед пов'язане 3 розвитком листкового апарату $[19,20]$. Ключову роль у продуктивності рослин відіграє фотосинтетична активність, яка значною мірою визначається площею листкової поверхні, кількістю і масою листків, мезоструктурною організацією листка. У результаті дослідження виявлено суттєву різницю за показниками кількість, площа i маса листків між рослинами дослідних i контрольного варіантів (табл. 1). За дії препаратів у період формування і росту коробочок зазначені вище показники були більшими у порівнянні з контролем, що свідчить про формування потужнішого донорного потенціалу фотосинтетичного апарату. Встановлено, що зростання загальної площі, кількості та маси листків у рослин дослідних варіантів зумовлене збільшенням кількості пагонів другого порядку в порівнянні з контролем. 
Проте урожайність рослин залежить не лише від площі листкової поверхні, але й значною мірою від особливостей внутрішньої будови листка, які в науковій літературі називають «мезоструктурою». Виявлено, що за дії хлормекватхлориду відбувалося достовірне збільшення показника питомої маси листків, який характеризує масу одиниці площі листка, та зменшення цього показника у варіантах із використанням трептолему та суміші препаратів.

Аналіз мезоструктурної організації листків маку, оброблених регуляторами росту, свідчить про істотне зростання товщини листків у всіх дослідних варіантах за рахунок розростання асиміляційної паренхіми (хлоренхіми) - ключової фотосинтетичної тканини листків. Потовщення шару хлоренхіми відбувалося за рахунок кращого розвитку ії клітин, лінійні розміри яких за дії суміші препаратів зростали у порівнянні з контролем (табл. 2).

Таблиия 2

Вплив регуляторів росту на мезоструктуру рослин маку олійного (стадія молочної стиглості)

\begin{tabular}{|c|c|c|c|c|}
\hline Показник & Контроль & $\begin{array}{c}\text { Суміш } \\
\text { препаратів }\end{array}$ & $\begin{array}{c}\text { Трептолем } \\
0,035 \text { мл/л }\end{array}$ & ХМХ 0,5\%-й \\
\hline Маса одиниці площі листка г/дм ${ }^{2}$ & $0,31 \pm 0,013$ & $* 0,263 \pm 0,011$ & $0,297 \pm 0,011$ & $* 0,359 \pm 0,012$ \\
\hline Товщина листка, мкм & $233,3 \pm 5,91$ & $* 289,09 \pm 5,49$ & $* 267,1 \pm 5,42$ & $* 292,6 \pm 5,99$ \\
\hline Товщина хлоренхіми, мкм & $127,5 \pm 2,93$ & $* 177,21 \pm 2,37$ & $1 * 52,1 \pm 2,12$ & $* 169,7 \pm 2,06$ \\
\hline Довжина клітин хлоренхіми, мкм & $43,7 \pm 0,92$ & $* 54,5 \pm 1,13$ & $* 50,1 \pm 1,41$ & $* 52,8 \pm 1,07$ \\
\hline Ширина клітин хлоренхіми, мкм & $22,9 \pm 0,84$ & $* 35,4 \pm 0,76$ & $* 31,9 \pm 0,93$ & $* 33,9 \pm 1,04$ \\
\hline $\begin{array}{c}\text { Вміст суми хлорофілів (а+в), } \\
\text { \% на масу сирої речовини }\end{array}$ & $0,22 \pm 0,002$ & $* 0,26 \pm 0,003$ & $* 0,28 \pm 0,004$ & $* 0,25 \pm 0,003$ \\
\hline
\end{tabular}

Примітки: *-різниця достовірна при $\mathrm{P} \leq 0,05$; суміш препаратів - трептолем $(0,035$ мл/л) + ХМХ 05\%-й

При цьому необхідно відзначити що чітка диференціація асиміляційної паренхіми (хлоренхіми) на стовпчасту та губчасту у рослин маку олійного відсутня. Збільшення частки хлоренхіми в загальній структурі листків внаслідок формування більших за розмірами асиміляційних клітин за дії препаратів є позитивним чинником, який впливає на вміст пігментів та фотосинтетичні процеси. Отримані нами дані свідчать також, що застосовані препарати суттєво збільшують вміст хлорофілів у листках маку. Аналогічний вплив ретарданту паклобутразолу встановлено на рослини Camelina sativa L. Crantz [21].

У літературі є достатньо даних про те, що існує чітка залежність між інтенсивністю росту, фотосинтезу, дихання та азотним живленням рослин [7]. Дані щодо впливу регуляторів росту на вміст азоту в олійних культурах $є$ поодинокими $[13,14]$.

Використання регуляторів росту на рослинах маку призводило до зменшенням вмісту загального азоту в коренях і листках як в контролі, так і в рослин дослідних варіантів (табл. 3).

Максимальна кількість азотовмісних речовин у листках і коренях відзначалася на початкових етапах дослідження, при цьому загальний вміст азоту у листках був значно вищим, порівняно з коренями. До кінця вегетації вміст азоту у тканинах вегетативних органів суттєво зменшувався.

Аналіз літературних даних свідчить про вплив регуляторів росту на вміст елементів мінерального живлення (фосфору та калію) в вегетативних органах рослин. Застосування хлормекватхлориду спричинювало зниження вмісту фосфору в листках цукрового буряка i коренеплодах та одночасне зростання вмісту калію відповідно [2]. При застосуванні триазолпохідного препарату паклобутразолу на рослинах картоплі спостерігалося зростання вмісту калію на початку періоду вегетації і зменшення їх вмісту наприкінці [16], використання препарату на рослинах ріпаку не викликала змін у вмісті калію в листках [12]. 
Вплив регуляторів росту на вміст елементів мінерального живлення у вегетативних органах рослин маку олійного

\begin{tabular}{|c|c|c|c|c|c|}
\hline $\begin{array}{c}\text { Фенологічна } \\
\text { стадія } \\
\text { росту }\end{array}$ & $\begin{array}{c}\text { Орган } \\
\text { рослини }\end{array}$ & Контроль & XMX 0,5\%-й & $\begin{array}{l}\text { Трептолем } \\
0,035 \text { мл/л }\end{array}$ & $\begin{array}{c}\text { Суміш } \\
\text { препаратів }\end{array}$ \\
\hline \multicolumn{6}{|c|}{ Вміст загального азоту, \% на суху речовину } \\
\hline \multirow{2}{*}{ цвітіння } & Корінці & $1,64 \pm 0,015$ & $1,63 \pm 0,01$ & $* 1,72 \pm 0,005$ & $* 1,59 \pm 0,01$ \\
\hline & Листки & $3,89 \pm 0,04$ & $4,07 \pm 0,06$ & $3,81 \pm 0,03$ & $* 3,77 \pm 0,003$ \\
\hline \multirow{2}{*}{$\begin{array}{l}\text { молочної } \\
\text { стиглості }\end{array}$} & Корінці & $1,38 \pm 0,015$ & $1,37 \pm 0,015$ & $1,42 \pm 0,01$ & $* 1,33 \pm 0,005$ \\
\hline & Листки & $3,58 \pm 0,03$ & $* 3,31 \pm 0,015$ & $* 3,24 \pm 0,003$ & $* 3,06 \pm 0,003$ \\
\hline \multirow{2}{*}{$\begin{array}{l}\text { воскової } \\
\text { стиглості }\end{array}$} & Корінці & $1,29 \pm 0,03$ & $* 1,13 \pm 0,02$ & $* 1,19 \pm 0,01$ & $1,24 \pm 0,03$ \\
\hline & Листки & $2,96 \pm 0,025$ & $* 2,85 \pm 0,02$ & $* 2,80 \pm 0,02$ & $* 2,67 \pm 0,00$ \\
\hline \multicolumn{6}{|c|}{ Вміст фосфору мг/г сухої речовини } \\
\hline \multirow{2}{*}{ цвітіння } & Корінці & $5,61 \pm 0,10$ & $5,83 \pm 0,11$ & $5,4 \pm 0,12$ & $5,63 \pm 0,09$ \\
\hline & Листки & $7,65 \pm 0,15$ & $* 6,45 \pm 0,14$ & $* 6,55 \pm 0,13$ & $* 6,33 \pm 0,14$ \\
\hline \multirow{2}{*}{$\begin{array}{l}\text { молочної } \\
\text { стиглості }\end{array}$} & Корінці & $4,38 \pm 0,09$ & $* 5,23 \pm 0,07$ & $* 4,9 \pm 0,06$ & $* 4,9 \pm 0,08$ \\
\hline & Листки & $8,13 \pm 0,13$ & $* 7,53 \pm 0,12$ & $* 7,43 \pm 0,09$ & $* 7,56 \pm 0,07$ \\
\hline \multirow{2}{*}{$\begin{array}{l}\text { воскової } \\
\text { стиглості }\end{array}$} & Корінці & $3,75 \pm 0,01$ & $* 3,43 \pm 0,02$ & $3,6 \pm 0,03$ & $* 3,28 \pm 0,01$ \\
\hline & Листки & $9,23 \pm 0,16$ & $* 8,58 \pm 0,15$ & $* 8,18 \pm 0,12$ & $* 8,65 \pm 0,11$ \\
\hline \multicolumn{6}{|c|}{ Вміст калію мг/г сухої речовини } \\
\hline \multirow{2}{*}{ цвітіння } & Корінці & $13,82 \pm 0,11$ & $* 14,25 \pm 0,09$ & $14,12 \pm 0,08$ & $* 14,41 \pm 0,09$ \\
\hline & Листки & $15,59 \pm 0,14$ & $* 16,49 \pm 0,13$ & $* 16,15 \pm 0,09$ & $* 14,61 \pm 0,11$ \\
\hline \multirow{2}{*}{$\begin{array}{l}\text { молочної } \\
\text { стиглості }\end{array}$} & Корінці & $12,11 \pm 0,11$ & $* 11,49 \pm 0,15$ & $* 11,32 \pm 0,11$ & $* 11,39 \pm 0,13$ \\
\hline & Листки & $13,61 \pm 0,23$ & $* 12,39 \pm 0,19$ & $* 12,23 \pm 0,15$ & $* 10,64 \pm 0,12$ \\
\hline \multirow{2}{*}{$\begin{array}{l}\text { воскової } \\
\text { стиглості }\end{array}$} & Корінці & $10,73 \pm 0,13$ & $* 9,95 \pm 0,15$ & $10,52 \pm 0,09$ & $* 9,28 \pm 0,12$ \\
\hline & Листки & $10,01 \pm 0,25$ & $* 9,66 \pm 0,21$ & $9,94 \pm 0,15$ & $* 9,32 \pm 0,18$ \\
\hline
\end{tabular}

Примітки: * - різниця достовірна при $\mathrm{P} \leq 0,05$; суміш препаратів - трептолем $(0,035$ мл/л) + ХМХ 05\%-й

Аналіз отриманих результатів свідчить про зростання вмісту фосфору в листках протягом вегетації в рослин маку контрольного і дослідного варіантів, що свідчить про важливу роль вищезазначеного елемента в фотосинтетичних процесах у період формування і росту плодів. При цьому на кінець вегетації вміст фосфору був нижчим у листках в усіх дослідних варіантах проти контролю (табл. 4). Вміст фосфору в коренях маку зменшується протягом вегетації в усіх варіантах досліду. На нашу думку, це пояснюється посиленим відтоком даного елементу до плодів, які в цей час інтенсивно формуються.

Загальновідомою $є$ роль калію в регуляції ростових процесів, транспорту асимілятів до репродуктивних органів. 3'ясовано також, що низьке забезпечення рослин олійних культур цим елементом суттєво гальмує синтез ліпідів [1].

Нами також встановлено, що за дії регуляторів росту зменшується вміст калію у листках відносно контролю. Аналогічна тенденція прослідковується для коренів, вміст калію був нижчим порівняно з контролем в усіх варіантах досліду впродовж всього періоду вегетації (табл. 3). На кінець цього періоду вміст елементу як в листках, так і в коренях зменшувався. Що, очевидно, пов'язано з посиленням відтоку елемента до генеративних органів, які формуються.

Відомо, що надходження, перерозподіл основних елементів мінерального живлення та підтримання їх певного балансу під дією регуляторів росту рослин сприяє покращенню продуктивності культур [7, 12, 16]. Зміни в балансі фізіологічно активних речовин та функціонуванні системи джерело асимілятів - стік призводили до більш активного потоку пластичних речовин в бік генеративних органів - коробочок, що зумовлювало зростання врожайності маку олійного. Так за дії суміші препаратів цей показник складав $10,51 \pm 0,26 *$ 
(ц/га), трептолему $10,14 \pm 0,23 *$, хлормекватхлориду $9,5 \pm 0,26 *$ відносно $8,4 \pm 0,25$ (ц/га) у варіанті без обробки.

Вплив препаратів проявився у змінах структури врожаю. Так, в умовах дрібноділянкового досліду одночасно $з$ кількістю коробочок зростала маса тисячі насінин $\mathrm{i}$ маса насіння в коробочці (рис.).
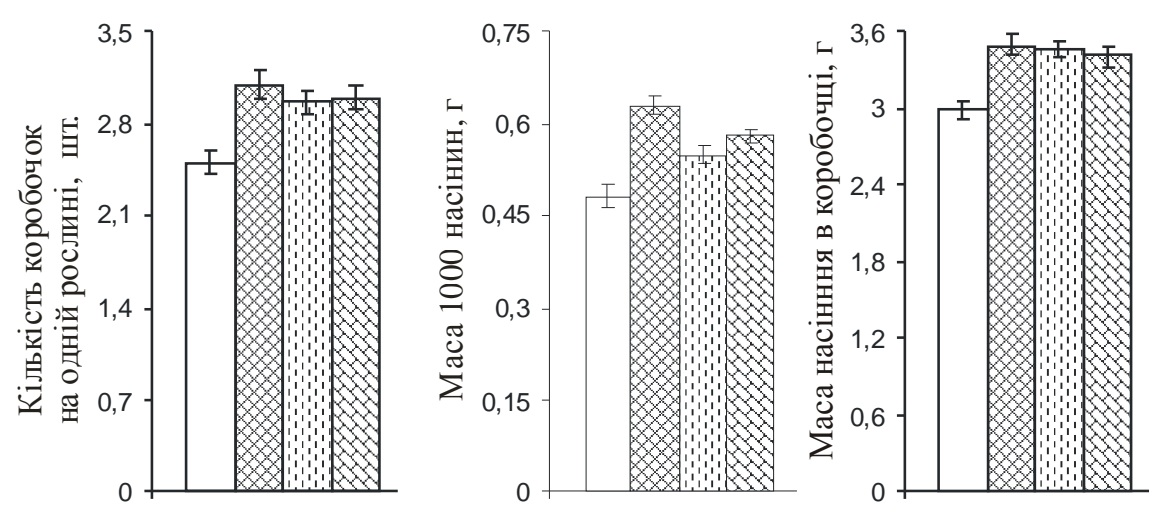

Рис. Вплив регуляторів росту на структуру урожаю маку олійного: $\square-$ контроль, - суміш трептолему (0,035мл/л) та 0,5\%-го хлормекватхлориду, 遮- - трептолем $(0,035$ мл/л), -0,5\%-й хлормекватхлорид

\section{Висновки}

Застосування регуляторів росту фазу бутонізації призводить до підвищення продуктивності культури маку олійного. За дії препаратів відбувається корекція донорно-акцепторних відносин у рослині, яка реалізується через перерозподіл асимілятів з вегетативних органів на потреби карпогенезу. Уповільнення лінійного росту на початку вегетації за дії хлормекватхлориду та підвищення висоти рослин під впливом трептолему й суміші препаратів призводили до інтенсивного галуження стебла, формування більшої кількості листків, листкової поверхні, оптимізації мезоструктури листків. Формування потужнішої акцепторної сфери пов'язане 3 посиленням галуження стебла i, відповідно, закладкою більшої кількості плодів - основних акцепторів асимілятів у другу половину вегетації. Збільшення навантаження рослини плодами у рослин дослідних варіантів визначало і більш інтенсивний потік до них азотовмісних сполук та елементів живлення, що в підсумку і забезпечило зростання урожаю насіння.

1. Верещагин А.Г. Шестнадцатый Международный симпозиум по липидам растений (1-4 июня 2004 г., Будапешт, Венгрия) / А.Г. Верещагин // Физиология растений. — 2005. — Т. 52, № 3. — С. 467-474.

2. Гуляєв Б.І. Вплив хлормекватхлориду та естерону на засвоєння цукровим буряком елементів мінерального живлення / Б.І. Гуляєв, А.Б. Карлова, Д.А. Кірізій // Физиология и биохимия культ. растений. - 2007. - Т. 39, № 5. - С. 401-408.

3. Доспехов Б.А. Методика полевого опыта (с основами статистической обработки результатов исследований) / Б. А. Доспехов. - М.: Альянс, 2011. - 352 с.

4. Казаков Є.О. Методологічні основи постановки експерименту з фізіології рослин / Є.О. Казаков. К.: Фітосоціоцентр, 2000. - 272 с.

5. Колісник А. В. Вплив N-оксидів піридину (івіну і триману) та кінетину на азотний метаболізм пшениці / А. В. Колісник, М. В. Драга, С. А. Шумік, М. М. Мусієнко // Физиология и биохимия культ. растений. - 2000. - Т. 32. — № 5. - С. 394-400.

6. Кур'ята В. Г. Ретарданти - модифікатори гормонального статусу рослин / Кур'ята В. Г. // Фізіологія рослин: проблеми та перспективи розвитку. Київ. - 2009. - Т. 1. — С. 565-589.

7. Кур'ята В. Г. Фізіолого-біохімічні механізми дії ретардантів і етиленпродуцентів на рослини ягідних культур : дис. ... доктора біол. наук : 03.00.12 / Кур’ята Володимир Григорович. — К., 1999. — 318 с.

8. Курьята В. Г. Действие ретардантов на мезоструктуру листьев малины / В. Г. Курьята // Физиология и биохимия культ. растений. - 1998. - Т. 30, № 2. — С. 144-149. 
9. Методы биохимического исследования растений / [А. И. Ермаков, В. В. Арасимович, Н. П. Ярош и др.]; под ред. А. И. Ермакова. — [3-е изд., перераб., доп.]. — Л. : Агропромиздат, Ленингр. отд-ние, 1987. - $430 \mathrm{c}$.

10. Персикова Т. Ф. Продуктивность люпина узколистого в условиях Беларуси / Т. Ф. Персикова, А.Р. Цыганов, А. В. Какшинцев. - Минск : ИВЦ Минфина, 2006. - 179 с.

11. Прусакова Л. Д. Синтетические регуляторы онтогенеза растений / Л. Д. Прусакова, С. И. Чижова // Природные и синтетические регуляторы онтогенеза растений ; под ред. Н. И. Якушкиной. - М. № 2. - 1990. - С. 84-124.

12. Рогач В. В. Дія ретардантів на морфогенез, продуктивність і склад вищих жирних кислот олії ріпаку / В. В. Рогач, В. Г. Кур'ята, С. В. Поливаний. - Вінниця: ТОВ «Нілан-ЛТД», 2016. - 156 с.

13. Рогач В. В. Накопичення і перерозподіл вуглеводів і азотовмісних сполук між органами рослин ріпаку в онтогенезі за дії хлормекватхлориду / В. В. Рогач // Агробіологія — 2010. — Вип. 4 (80). — C. $45-50$.

14. Рогач Т. І. Накопичення та перерозподіл вуглеводів і азотовмісних сполук між органами рослин соняшника в онтогенезі за дії хлормекватхлориду / Рогач Т. І., Кур'ята В. Г. // Зб. наук. праць ВНАУ. - 2011. — № 8 (48). - С. 49-54.

15. Сакало В. Д. Регуляция эмистимом С и бетастимулином метаболизма сахарозы и продуктивности сахарной свеклы / В. Д. Сакало, С. П. Пономаренко, В. М. Курчий // Агрохимия. — 2001. — № 10. - C. $49-55$.

16. Ткачук О. О. Дія ретардантів на морфогенез, період спокою і продуктивність картоплі: монографія / О. О. Ткачук, В. Г. Кур'ята. - Вінниця, ТОВ «Нілан-ЛТД», 2015. - 152 с.

17. Шевчук О. А. Накопичення та перерозподіл елементів мінерального живлення у вегетативних органах рослин цукрового буряка за дії ретардантів / О. А. Шевчук, В. Г. Кур'ята // Збірник наукових праць ВДАУ. - Вінниця, 2007. - Вип. 32. - С. 18-26.

18. Шляхи регулювання функцій мікробних угруповань грунту в аспекті біологізації землеробства і стійкого розвитку агроекосистем / Г. О. Іутинська // Сільськогосподарська мікробіологія: Міжвід. темат. наук. зб. - Чернігів. - 2006. - Вип. 3. - С. 7-18.

19. Carvalho M. E. A. Are plant growth retardants a strategy to decrease lodging and increase yield of sunflower / M. E. A. Carvalho, C. P. R. Castro // Comunicata Scientiae. - 2016. — 7 (1). — P. 154-164.

20. Kasem M. M. Studding the Influence of Some Growth Retardants as a Chemical Mower on Ryegrass (Lolium perenne L.) / M. M. Kasem, // Journal of Plant Sciences. — 2015. — 3 (5). — P. 255-258.

21. Kumar, S. Paclobutrazol treatment as a potential strategy for higher seed and oil yield in field-grown Camelina sativa L. // G. Sreenivas, A. Guha // Crantz. BSK Research Notes. — 2012. — 5(1). — P. 1-13.

\section{References}

1. Vereshchagin A.G. Shestnadtsatyy Mezhdunarodnyy simpozium po lipidam rasteniy (1-4 iiunia 2004 g., Budapesht, Vengriia) / A.G. Vereshchagin // Fiziologiia rasteniy. — 2005. — T. 52, No 3. — S. 467-474. (in Russian).

2. Huliaiev B.I. Vplyv khlormekvatkhlorydu ta esteronu na zasvoiennia tsukrovym buriakom elementiv mineral'noho zhyvlennia / B.I. Huliaiev, A.B. Karlova, D.A. Kiriziy // Fyzyolohyia y byokhymyia kul't. rastenyy. - 2007. - T. 39, No 5. - S. 401-408. (in Ukrainian).

3. Dospekhov B.A. Metodika polevogo opyta (s osnovami statisticheskoy obrabotki rezul'tatov issledovaniy) / B. A. Dospekhov. - M.: Al'ians, 2011. — 352 s. (in Russian).

4. Kazakov Ie.O. Metodolohichni osnovy postanovky eksperymentu z fiziolohii roslyn / Ie.O. Kazakov. - K.: Fitosotsiotsentr, 2000. - 272 s. (in Ukrainian).

5. Kolisnyk A. V. Vplyv N-oksydiv pirydynu (ivinu i trymanu) ta kinetynu na azotnyy metabolizm pshenytsi / A. V. Kolisnyk, M. V. Draha, S. A. Shumik, M. M. Musiienko // Fyzyolohyia y byokhymyia kul't. rastenyy. - 2000. - T. 32. - No 5. - S. 394-400. (in Ukrainian).

6. Kur'iata V. H. Retardanty - modyfikatory hormonal'noho statusu roslyn / Kur'iata V. H. // Fiziolohiia roslyn: problemy ta perspektyvy rozvytku. Kyiv. - 2009. - T. 1. - S. 565-589. (in Ukrainian).

7. Kur'iata V. H. Fizioloho-biokhimichni mekhanizmy dii retardantiv i etylenprodutsentiv na roslyny iahidnykh kul'tur : dys. ... doktora biol. nauk : 03.00.12 / Kur'iata Volodymyr Hryhorovych. — K., 1999. - 318 s. (in Ukrainian).

8. Kur'iata V. G. Deystvie retardantov na mezostrukturu list'ev maliny / V. G. Kur'iata // Fiziologiia i biokhimiia kul't. rasteniy. - 1998. - T. 30, No 2. - S. 144-149. (in Russian).

9. Metody biokhimicheskogo issledovaniia rasteniy / [A. I. Ermakov, V. V. Arasimovich, N. P. Iarosh i dr.]; pod red. A. I. Ermakova. — [3-e izd., pererab., dop.]. — L. : Agropromizdat, Leningr. otd-nie, 1987. 430 s. (in Russian).

146 ISSN 2078-2357. Наук. зап. Терноп. нац. пед. ун-ту. Сер. Біол., 2019, № 1 (75) 
10. Persikova T. F. Produktivnost' liupina uzkolistogo v usloviiakh Belarusi / T. F. Persikova, A.R. Tsyganov, A. V. Kakshintsev. - Minsk : IVTs Minfina, 2006. - 179 s. (in Russian).

11. Prusakova L. D. Sinteticheskie reguliatory ontogeneza rasteniy / L. D. Prusakova, S. I. Chizhova // Prirodnye i sinteticheskie reguliatory ontogeneza rasteniy ; pod red. N. I. Iakushkinoy. - M. - No 2. 1990. - S. 84-124. (in Russian).

12. Rohach V. V. Diia retardantiv na morfohenez, produktyvnist' i sklad vyshchykh zhyrnykh kyslot olii ripaku / V. V. Rohach, V. H. Kur'iata, S. V. Polyvanyy. — Vinnytsia: TOV «Nilan-LTD», 2016. — 156 s. (in Ukrainian).

13. Rohach V. V. Nakopychennia i pererozpodil vuhlevodiv i azotovmisnykh spoluk mizh orhanamy roslyn ripaku v ontohenezi za dii khlormekvatkhlorydu / V. V. Rohach // Ahrobiolohiia — 2010. — Vyp. 4 (80). - S. 45-50. (in Ukrainian).

14. Rohach T. I. Nakopychennia ta pererozpodil vuhlevodiv i azotovmisnykh spoluk mizh orhanamy roslyn soniashnyka v ontohenezi za dii khlormekvatkhlorydu / Rohach T. I., Kur'iata V. H. // Zb. nauk. prats' VNAU. - 2011. — No 8 (48). - S. 49-54. (in Ukrainian).

15. Sakalo V. D. Reguliatsiia emistimom $\mathrm{S}$ i betastimulinom metabolizma sakharozy i produktivnosti sakharnoy svekly / V. D. Sakalo, S. P. Ponomarenko, V. M. Kurchiy // Agrokhimiia. - 2001. — No 10. — S. 4955. (in Russian).

16. Tkachuk O. O. Diia retardantiv na morfohenez, period spokoiu i produktyvnist' kartopli: monohrafiia / O. O. Tkachuk, V. H. Kur'iata. - Vinnytsia, TOV «Nilan-LTD», 2015. - 152 s. (in Ukrainian).

17. Shevchuk O. A. Nakopychennia ta pererozpodil elementiv mineral'noho zhyvlennia u vehetatyvnykh orhanakh roslyn tsukrovoho buriaka za dii retardantiv / O. A. Shevchuk, V. H. Kur'iata // Zbirnyk naukovykh prats' VDAU. - Vinnytsia, 2007. - Vyp. 32. - S. 18-26. (in Ukrainian).

18. Shliakhy rehuliuvannia funktsiy mikrobnykh uhrupovan' gruntu $\mathrm{v}$ aspekti biolohizatsii zemlerobstva $\mathrm{i}$ stiykoho rozvytku ahroekosystem / H. O. Iutyns'ka // Sil's'kohospodars'ka mikrobiolohiia: Mizhvid. temat. nauk. zb. - Chernihiv. - 2006. - Vyp. 3. - S. 7-18. (in Ukrainian).

19. Carvalho M. E. A. Are plant growth retardants a strategy to decrease lodging and increase yield of sunflower / M. E. A. Carvalho, C. P. R. Castro // Comunicata Scientiae. - 2016. - 7 (1). — P. 154-164.

20. Kasem M. M. Studding the Influence of Some Growth Retardants as a Chemical Mower on Ryegrass (Lolium perenne L.) / M. M. Kasem, // Journal of Plant Sciences. — 2015. — 3 (5). — P. 255-258.

21. Kumar, S. Paclobutrazol treatment as a potential strategy for higher seed and oil yield in field-grown Camelina sativa L. // G. Sreenivas, A. Guha // Crantz. BSK Research Notes. - 2012. - 5(1). — P. 1-13.

\section{S.V. Polyvanyi}

Mychailo Kotsubinskyi Vinnitsya State Pedagogical University, Ukraine

\section{INFLUENCE OF GROWTH REGULATORS ON THE PECULIARITIES OF THE REDISTRIBUTION OF ELEMENTS OF INORGANIC NUTRITION AND PRODUCTIVITY OF OIL POPPY PLANTS}

In the conditions of the field experiment, the effect of chlormequat chloride, treptolem and a complex of treptolem and chlormequat chloride on the morphological features and the accumulation and redistribution of nitrogen, phosphorus and potassium in oil poppy plants are studied. It is established that the treatment of poppy plants with growth regulators caused an increase in the stem branching, an increase in the number, area and mass of leaves. The treatment with treptolem, chormequat chloride, a complex of the preparations led to thickening of the basic assimilation tissue of the leaf chlorenchyme due to the growth of its cells. As a result of these changes in the photosynthetic apparatus, the donor potential of oil poppy plants was substantially increased. Due to the increased stem branching under the action of preparations, there was an additional number of new attracting centres - pods. This led to the redistribution of elements of inorganic nutrients towards the fruit formation.

Key words: Papaver somniferum L., plant growth regulators, mesostructure of leaves, morphogenesis, elements of mineral nutrition, productivity

Надійшла 13.11.2018. 